\title{
Versions by Thomas, Lord Fairfax of Some Poems by Mantuan and Other Italian Neo-Latin Writers
}

\author{
LEE PIEPHO
}

In 1858 the Bodleian Library purchased from Edward Bliss, Anthony à Wood's editor, the autograph manuscript of a collection of verse composed by Thomas, third Lord Fairfax,${ }^{1}$ leader of the Parliamentary forces during the English Civil War and, with his daughter Mary, the object of Andrew Marvell's praise in his famous poem "Upon Appleton House." The collection, Bodleian MS. Fairfax 40, consists of paraphrases and translations as well as original poems, most of which are assumed to have been written after June, 1650, during Fairfax's eight years of retirement at Nun Appleton House in Yorkshire. Although portions of this collection have been edited at various times over the years, ${ }^{2}$ an interesting group of translations and paraphrases from the Neo-Latin verse of Giovanni Pontano, Marcellus Palingenius, and Baptista Mantuanus ("Mantuan" to most English readers) remains as yet in manuscript; and it is this group of poems that I edit here now for the first time.

In addition to their association with two major figures of mid-seventeenthcentury England, the poems are noteworthy because they are among the few instances of explicitly identified versions of works by Mantuan and other Italian Renaissance poets recorded in Margaret Crum's First-Line Index. ${ }^{3}$ But as I hope to make clear, closer scrutiny reveals not only the probability of intervening texts for $\mathrm{F}$ airfax's versions but of a specific nonliterary reason for his interest in the work of these distinguished quattrocento and early cinquecento writers.

Fairfax divided his collection into two groups of poems. The first group takes up 551 of the manuscript's 650 pages, 388 pages of this being devoted to a metrical paraphrase of the Psalms. A separate title, "The Recreations of my Solitude T.F.," marks off the second grouping, a farrago of verse concluding with an eclogue by Fairfax's uncle, the famous translator of Tasso. The versions of Mantuan, Pontano, and Palingenius begin on p. 606, immediately following "A Carracter of the Romish Church by Francisco Petrarca" (printed by Bliss) taken from Canzoniere 
136 and 138. The text from Fairfax's collection printed below is given literatim, with page numbers in brackets opposite each first line. Full Latin texts appear in the footnotes for all but the epigram by Pontano.

Pontanus writes this

epitaph on Lucretia

daughter of Alexander 6

Hoc tumulo dormit Lucretia nomine, sed re

Thais Alixandri [sic] filia sponsa nurus

Here Lies Lucretia in name, indeed yett more

Pope Alixander's daughter His \& his brothers whore

Baptista Mantua reproving the wicked Life of Sixtus 4

[p. 607] maketh the Divel give him this Entertainment in Hell

At tu implume caput $\& c^{4}$

Thou Bauld head Pope who is by Nature fram'd

To vice more horred then tis fitt be nam'd

Dost thou thinke thy sinnes will be the lighter

Or goe unpunish'd because of thy Mitter

No filthy wrech but as thy Lust thou served

So thy reward shall be as ther crimes deserved

\section{Mantua Ecloga 5}

[p. 608]

Heu Roma [sic] nunc sola pecunia regnat

Excilium $[$ sic $]$ virtus patititur $[$ sic $] \& c^{5}$

Alas at Rome nothing ther but mony raignes

Virtue's quite gone the City to stewes they change

Why so of sence art thou bereved quitt

To swaye war's weapones \& in blood delight

If from abroad men doe sweet Peace pocess

Thou rayses ware att home wch doth opress

Nor can thy haughty pride desend soe much

As in Rest her calme harbour once to touch

But Brother against Brother thou dost sett

And teacheth sones ther Fathers to forgett

Al mischeife thou art bold to enterprise

And hatchest in thy selfe all villanyes

To Lawes Just rules soe much regarde thou beares

As nether God, Man, Heaven or Hell thou feares

Palengenus A Papist thus describes

the monstrous corruptions of the

Romaine clargie

Sed tua praecipue non intret Lumina $[s i c]$ quisquam

Frater vel monachus $\& c^{6}$ 
Within thy doores noe Frier or Munck Let in Then this a greater mischeife none can bring They wolves in sheepe skins are yitt none regards

Not for devotion serves but for rewards

Wth fained shewes of Truth weake consience binds

Valid wth Religion Acts a thousand crimes

[p. 610]

Those that should be chast are such evell doers

As sels things Holy to spend on ther whores

What shame itt is the church should thus endure

Such bease [beasts?] as these yitt would be thought tis pure

$* * *$

As the original Latin texts demonstrate, only Fairfax's versions of Pontano's epigram and Mantuan's At tu implume can be described as translations. Indeed, what he describes as being based on Mantuan's fifth eclogue is so far removed from the original as to invite consideration of the sources for Fairfax's texts.

Granted that Mantuan's eclogues and Palingenius' Zodiacus vitae were common grammar school texts, we might initially conclude with Reed ( $p$. 243) that Fairfax had first come on two of the passages early in life, and had composed versions of them in English at that time. But Mantuan's Alphonsus was by no means a widely current text during the seventeenth century (unlike his eclogues, the work was never printed in England and after 1513 appeared only twice on the Continent, in the collected works of 1573 and $1576^{7}$ ). Pontano's epigram presents a still stranger case, since one does not find it in the major Renaissance editions of his works. ${ }^{8}$ Where it does appear is in the flood of antipapal literature produced during the period-as, indeed, do the other three texts Englished by Fairfax.

Pontano's epigram on Lucretia Borgia is something like a staple item in attacks on the papacy and hostile accounts of the life of Alexander VI. ${ }^{9}$ Palingenius' attack on the lechery of friars and monks had a similar notoriety during the period, although somewhat less currency. ${ }^{10}$ The passage from Mantuan's Alphonsus would seem, on the other hand, to be far less common in this body of literature. Indeed, that Fairfax's translation of it exists at all may be due to John Bale, the influential polemicist for the English reformation. A Carmelite monk before leaving the Catholic Church, Bale during his years in orders had filled a series of notebooks with extracts from the letters, sermons, and poetry of Mantuan, Vicar-General of the Carmelites and a prominent spokesman for reform of the Papal Curia. ${ }^{11}$ In his Acta romanorum pontificium, Bale's quarrelsome history of the popes, this reading in Mantuan's works bore unexpected fruit. Despite a list of over one hundred sources that prefaces Bale's survey, Mantuan's poems turn up again and again, especially in early chapters of the work. ${ }^{12}$ The application to Sixtus of the passage in Alphonsus is by no 
means so explicit as is the language of the Borgia epigram; ${ }^{13}$ it would therefore seem at least probable that Fairfax found the text from Alphonsus either in Bale's Acta (pp. 470-71) or in one of the diatribes that, like $A$ Looking-Glass for Papists, use Bale as a source.

The case for a textual source in anti-papal literature is even stronger for Fairfax's version of Mantuan's fifth eclogue. Comparison of Fairfax's poem with the passage in Mantuan shows that the Latin text provided him with matter for less than the first two lines. For the rest, Fairfax drew on various passages from Mantuan's In Romam bellis tumultuantem, an attack on Rome that refers to the strife between the Orsini and Colonna factions during the 1480's. Incorporated into Mantuan's Sylvae, In Romam bellis tumultuantum had, like the Alphonsus, little currency after the early sixteenth century. ${ }^{14}$ However, in a revised version of Matthias Flacius' Catalogus testium veritatis, a vast compendium of writings critical of the papacy, passages from the work are quoted in a form relevant to Fairfax's poem. Beginning with the lines from Mantuan's fifth eclogue-

In Romam vero, 5. Ecloga:

Si quid Roma dabit, nugas dabit. accipt aurum

Verba dat. heu Romae nunc sola pecunia regnat,

Exilium virtus patitur, \&c.

- the revised version of the protestant church historian's compendium continues immediately with the opening lines and conclusion of In Romam bellis tumultuantem:

Ex primo libro Sylvarum:

Roma, quid insanis toties? quid sanguine gaudes?

Quid geris imbelli spicula tanta manu?

Quo vesana ruis? studiosque amaris inani

Iam senio lassas debilitante manus?

Et paulo post:

Fas et jura negas, homines et numina fallis

Nec Iovis imperium nec Phlegethonta times.

Singula texentem convitia deseret aetas,

Tantum ac tale tuae est improbitatis onus.

Romanis pater est Mavors, lupa Martia nutrix,

Haec hominum mores ingeniumque docent.

Vivere qui sancte cupitis discedite, Romae

Omnia cum liceant, non licet esse bonum. ${ }^{15}$

The first passage quoted from In Romam bellis tumultuantem supplied Fairfax with lines 3-4 of his poem, while the second passage is clearly the basis for his conclusion. The remainder is based on two couplets also found in Mantuan's poem: 
Si foris arma tacent, tu bella domestica tentas,

$\mathrm{Nec}$ feritas requiem ferre superba potest....

Tu frates in bella vocas, in pignora patres

Et scelus omne audes, et paris omne nephas. ${ }^{16}$

Fairfax ${ }^{17}$ or some intervening writer ${ }^{18}$ working with the 1608 edition of Flacius' compendium would seem to have returned to In Romam bellis tumultuantem, taking from it the additional four lines. In all likelihood, Fairfax then versified material from the passages in the order of their appearance in the commonplace book into which he had copied them.

All this does not mean that he had not read Mantuan's eclogues as a boy. His handling of Mantuan's fifth eclogue does indicate, however, that Fairfax's enduring interest in the Neo-Latin poet is essentially polemical. For him, as for Flacius and Bale, Mantuan is important because he bears witness to the iniquities of Rome. ${ }^{19}$ This polemical spirit helps to explain why Fairfax includes the names of the authors from whom he is translating. (The practice is by no means typical of him: "The Solitude," for instance, is nowhere designated as a version of Saint Amant's poem.) Concluding an attack on lechery among priests, the anonymous author of The Abuses of the Romish Church Anatomized remarks: "But least [my critics] should say, that these testimonies have been devised by men of our profession, to disgrace them and theirs, let us heare what Mantuan, one of their own sect, saith of them. . .." ${ }^{20}$ As one of Fairfax's titles would have it: "Palengenus [sic] A Papist thus describes the monstrous corruptions of the Romaine clargie." That Mantuan, like Palingenius, Petrarch, and Pontano, is a "one of their own sect" is for Fairfax, as for the author of The Abuses of the Romish Church, what finally seems to count. ${ }^{21}$

\section{Sweet Briar College}

\section{Notes}

1 Two other versions of this collection are known to exist. The first, like the Bodleian manuscript an autograph copy, is in the British Library (BL Add. MS. 11744,f.48). The second version, in the Brotherton Library at Leeds, is based on a larger compilation, now lost, of materials relating to the family made by Charles Fairfax of Menston in 1660 . See Hilton Kelliher, Andrew Marvell Poet and Politician 1621-78 (London: British Museum Publications, 1978), pp. 45-46.

2 Portions of the manuscript, including Fairfax's version of Saint Amant's "La Solitude," were printed in the biographies by C.R. Markham, A Life of the Great Lord Fairfax (London: Macmillan, 1870), pp. 415-27 and M.A. Gibb, The Lord General (London: L. Drummond, 1938), pp. 28191. By far the most extensive selection was edited by Edward Bliss Reed as Poems of Thomas Third Lord Fairfax from MS. Fairfax 40 in the Bodleian Library, Oxford (New Haven: Yale Univ. Press, 1901).

3 Fairfax's two translations from Mantuan are among only four listed by Crum. His translation from Pontano is one of two and his paraphrase from Palingenius is unique in her listing: First-Line Index of English Poetry 1500-1800 in Manuscripts of the Bodleian Library Oxford (Oxford Univ. Press, 1969), II, 1250, 1252. 
4 Opera omnia, ed. Laurentius Cuperus (Antwerp: Joannes Bellerus, 1576), vol. III, fol. 63r. Unless otherwise noted, all quotations from Mantuan's works are taken from this edition.

At tu implume caput cui tanta licentia quondam

Foemineos fuit in coitus, tua furta putabas

Hic quoque praetentu mitrae impunita relinqui?

Sic meruit tua foeda Venus, sic prodiga in omnem

Nequitiam, ad virtutis opus tua avara libido.

5 Opera omnia I, 74v:

Si quid Roma dabit, nugas dabit. accipit aurum,

Verba dat. Heu Romae nunc sola pecunia regnat;

Exsilium virtus patitur.

6 Zodiacus vitae (London: Thomas Marsh, 1574), pp. 136-37:

Sed tua praecipuè non intret limine quisquam

Frater, vel monachus, vel quavis lege sacerdos

Hos fuge, pestis enim nulla hac immanior: hi sunt

Faex hominum, fons stultitiae, sentina malorum

Agnorum sub pelle lupi, mercede colentes

Pietate Deum, falsa sub imagine recti

Decipiunt stolidos, ac religionis in umbra

Mille actus vetitos \& mille piacula condunt:

Raptores, moechi, puerorum corruptores,

Luxuriae atque gulae famuli: caelestia vendunt.

7 Edmondo Coccia, Le edizioni delle opere del Mantovano, Collectanea Bibliographica Carmelitana No. 2 (Rome: Institutum Carmelitanum, 1970), p. 112.

8 For a text, Crum(op. cit., I, 342) cites Pia quaedam vetustissimaque poemata noted below (n. 9). The epigram is also missing from the modern editions of Pontano's works by Benedetto Soldati, Johannes Oeschger, and Liliana Monti Sabia.

9 The epigram is quoted and identified as Pontano's in the works by John Bale (p. 462) and Matthias Flacius (1608 ed., col. 18) discussed below. It also appears, to go no further, in: Pia quaedam vetustissimaque poemata ... cum praefatione Matt. Flacii Illyrici (Magdeburg, 1552), p. 392; Thomas Beard, Antichrist the Pope of Rome: or the Pope of Rome is Antichrist (London: Issac Jaggard for John Bellamie, 1625), p. 30; and John Menzies, Roma Mendax (London: for Abel Roper, 1675), p. 358.

10 In the Biographie universelle (Paris: Michaud Frères, 1811-62), it is described as a "passage si connu" (XXVI, 406). See, e.g., The Popes Deadly Wound (London: T.S. for Nathaniel Newberie, 1621) in which, discussing the lechery of priests, Thomas Clarke cites the testimony of "their" Palingenius: "Let no Frier, Monke, or any other Prest come within thy dores; take heed of them, no greater mischeife, they are the dregges of men, the fountains of Folly, the sinks of sinne, Wolves under Lambes skinnes, deceiving the simple with a false shew of honesty: under the shaddow of Religion, [they] hide a thousand of unlawfull acts: committers of Rapes, abusers of boyes: the Priests and Monkes that should be chaste, spend night and day, eyther openly with whoores, or closely with boyes. O shame (sayeth hee) can the Church endure such hogges?" (p.46).

11 See Leslie Fairfield, John Bale: Mythmaker for the English Reformation (West Lafayette, Indiana: Purdue Univ. Press, 1976), pp. 11-12, 160.

12 E.g., pp. 169, 173, 469, 470-71, 473 in the 1615 edition of Bale's Acta: Scriptores duo Anglici coaetanei ... de vitiis pontificium Romanorum (Leyden: Georgius Abraham a Marsse, sumptibus Henrici Laurentii, 1615).

13 Jodicus Badius Ascanius, who commented on the passage in Alphonsus, observes that in his manuscript he finds a note connecting it with "S.P. or. minorum." Badius remarks that this can be interpreted as "S. Pontifex. ordinis minorum" (Sixtus was a Franciscan) but then observes coyly that "since the author of the note doesn't disentangle the matter, let me not dare to name so great a man (ego tantum virum cum author non explicet nominare hoc loco non ausim)." Mantuan, Opera poetica (Paris: Ascensius, 1513), vol. III, fol. 37v. 
14 After 1513, it appeared only twice: in the Opera of 1573 and of 1576. Coccia, op. cit., p. 123.

15 Catalogus testium veritatis...nova hac editione emendatior, et prioribus duplo auctior redditus... studio et cura S. G. S. Accessit appendix rerum et testimoniorum insignium ab anno 1517 ad anno 1600 (Geneva: Jacob Stoer and Jacob Chouet, 1608), col. 1920. The Catalogus was first printed by Oporinus at Basel in 1556 and again in 1562 "emendatior \& auctior editus" by Oporinus for himself and Paulus Machaeropoeus. In 1597 it appeared at Lyon printed by Antonius Candidus and edited, according to Brunet (Manuel du librarie, vol. 2, col. 1277), to the point of being rewritten by Simon Goulart. Only the Geneva edition of 1608, however, contains the passages from In Romam bellis tumultuantum and Mantuan's fifth eclogue. For help in confirming the material here and in $\mathrm{n} .17$ I should like to thank Carol Kaske of Cornell University as well as Anthony Amodeo at the Newberry Library, James Green at the University of Chicago Library, and Daniel Traister at the New York Public Library.

16 Opera omnia III, 261v, 262r.

17 During his residence at Nun Appleton House, Fairfax wrote a history of the Church up to the time of the Reformation (Markham, op. cit., p. 368), a project for which he no doubt consulted the Catalogus as well as Bale's Acta. His selection of texts from Petrarch's Canzoniere, the first and last in a series of three sonnets attacking the papal court at Avignon, seems less arbitrary when we note that in the 1608 edition of the Catalogus (col. 1770) the same sonnets appear with Latin translations. (All previous editions [see above, n. 15] quote in Latin only small portions, not the whole text of these sonnets.)

18 George Webb acknowledges using Flacius' compendium in his Catalogus Protestantium. See also the conclusion of Beard's Antichrist the Pope of Rome: "And thus I suppose I have sufficiently proved that God in all ages stirred up some witnesses of his truth, and reprovers of Antichristian errours: for further manifestation whereof, I referre the Reader to that famous book entitled, Catalogus testium veritatis..." (p. 422).

19 For further information on this aspect of Mantuan's reputation, see the introduction in my forthcoming edition of The Eclogues of Baptista Mantuanus.

20 The Abuses of the Romish Church Anatomized (London: Augustine Mathewes for John Grismand, 1623), sig. B2r.

21 Publication of portions of MS. Fairfax 40 has been made with the kind permission of the Bodleian Library. For assistance and advice, I should like to thank Nati Krivatsy and Letitia KennedySkipton at the Folger Shakespeare Library, where research for this article was carried out. 